УДК 618.146:618.2

DOI 10.11603/24116-4944.2017.1.7494

\author{
๑о. П. Гнатко ${ }^{1}$, Н. Г. Скурятіна ${ }^{1}$, Т. А. Бережна ${ }^{2}$ \\ ${ }^{1}$ Національний медичний університет імені О. О. Богомольия \\ ${ }^{2}$ ККЛ ЗТ № 2 Філія «ЦОЗ» ПАТ «Укрзалізниия», Київ

\section{КОМПЛЕКСНА ОЦІНКА СТАНУ СЛИЗОВОЇ ШИЙКИ МАТКИ ПІД ЧАС BAГITHOCTI}

\begin{abstract}
Мета дослідження - провести аналіз результатів комплексної оцінки стану шийки матки у здорових жінок протягом вагітності.

Матеріали та методи. Під спостереженням перебувало 76 здорових жінок, які були взяті на облік з приводу вагітності без патологічних змін шийки матки віком від 23 до 35 років. Контрольну групу складали 30 здорових невагітних жінок репродуктивного віку. Крім загальноклінічного обстеження, проводили кольпоскопічне, цитологічне та мікробіологічне дослідження, визначали рівень показників місцевого імунітету (імуноглобулінів (Ig) класів A, M, G та slgA) в I, II та III триместрах вагітності.

Результати дослідження та їх обговорення. Показано, що під час вагітності відбуваються фрізіологічні зміни слизової шийки матки, які встановлені за результатами досліджень. При кольпоскопічному дослідженні: посилення васкуляризації (14,5 \%), набряк епітелію (14,5\%), зміщення стику епітелію в бік ектоцервіксу (15,8 \%), децидуоз (7,9\%), німі йоднегативні зони (3 II триместру вагітності у 15,8 \%). Частота і характер виявлення даних змін зростала з пролонгацією вагітності. При цитологічному дослідженні виявлено наявність цитолізу клітин, переважання клітин проміжних шарів, ознак запалення $(14,5$ \%) і гіперкератозу (у 10,5 \% жінок з II триместру), частота яких зростала до III триместру вагітності. При вивченні показників місцевого імунітету відмічено підвищення

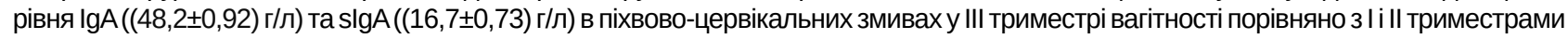
$(p<0,05)$, що свідчило про зростання захисних властивостей цервікального слизу перед пологами. В процесі вивчення стану шийки матки протягом вагітності виявлено дисплазію шийки матки легкого ступеня в III триместрі у 1 (1,3%) пацієнтки при кольпоскопії і у 2 (2,6 \%) - при цитологічному дослідженні.

Висновки. Комплексна оцінка стану слизової шийки матки у жінок із незміненою шийкою матки показала, що під час вагітності відбуваються зміни, які є наслідком гестаційної перебудови під впливом гормональних, метаболічних та імунологічних процесів, що притаманні фрізіологічній вагітності. Проведення і правильне трактування результатів кольпоскопічного, цитологічного, імунологічного скринінгу у вагітних щодо виключення підозри на наявність передракових та злоякісних процесів шийки матки дозволяють своєчасно встановити патологічний процес і забезпечити адекватне лікування.
\end{abstract}

Ключові слова: шийка матки; вагітність; кольпоскопія; цитологічне дослідження.

КОМПЛЕКСНАЯ ОЦЕНКА СОСТОЯНИЯ СЛИЗИСТОЙ ШЕЙКИ МАТКИ ВО ВРЕМЯ БЕРЕМЕННОСТИ

Цель исследования - провести анализ результатов комплексной оценки состояния шейки матки у здоровых женщин на протяжении беременности.

Материалы и методы. Под наблюдением состояло 76 здоровых женщин, которые были взяты на учет по беременности без патологических изменений шейки матки в возрасте 23-35 лет. Контрольную группу составили 30 здоровых небеременных женщин репродуктивного возраста. Кроме общеклинического обследования, проводилось кольпоскопическое, цитологическое и микробиологическое исследование, определение уровня показателей местного иммунитета (иммуноглобулинов (Ig) классов A, M, G и slgA) в I, II и III триместрах беременности.

Результаты исследования и их обсуждение. Показано, что во время беременности происходят фризиологические изменения слизистой шейки матки, которые установлены по результатам исследования. При кольпоскопическом исследовании: усиление васкуляризации (14,5\%), отечность эпителия (14,5\%), смещение стыка эпителия в сторону эктоцервикса (15,8\%), децидуоз (7,9\%), немые йоднегативные зоны (со II триместра беременности у 15,8 \%). Частота выявления данных изменений возростала с пролонгацией беременности. При цитологическом обследовании выявлено наличие цитолиза клеток, преобладание клеток промежуточных слоев, признаков воспаления (14,5 \%) и гиперкератоза (со II триместра у 10,5 \% женщин), частота которых увеличивалась к III триместру беременности. При изучении показателей местного иммунитета отмечено повышение уровня IgA $((48,2 \pm 0,92)$ г/л) и $\operatorname{sgA}((16,7 \pm 0,73)$ г/л) в вагинально-цервикальных смывах в III триместре беременности в сравнении с I и II триместрами $(p<0,05)$, что указывало на повышение защитных свойств шеечной слизи перед родами. В процессе изучения состояния шейки матки на протяжении беременности выявлено дисплазию шейки матки легкой степени в III триместре у 1 (1,3 \%) пациентки при кольпоскопии и у 2 (2,6 \%) - при цитологическом исследовании.

Выводы. Комплексная оценка состояния слизистой шейки матки у женщин с неизмененной шейкой матки показала, что во время беременности происходят изменения, которые являются следствием гестационной перестройки под влиянием гормональных, метаболических и иммунологических процессов, присущих физиологической беременности. Проведение и правильная трактовка результатов кольпоскопического, цитологического, иммунологического скрининга у беременных относительно исключения подозрения на наличие предраковых и злокачественных процессов шейки матки позволяют своевременно установить патологический процесс и обеспечить адекватное лечение.

Ключевые слова: шейка матки; беременность; кольпоскопия; цитологическое обследование.

COMPREHENSIVE ASSESSMENT OF CERVICAL MUCOSA DURING PREGNANCY

The aim of the study - to analyze the results of a comprehensive assessment of the cervix in healthy women during pregnancy.

Materials and Methods. 76 healthy women registered for pregnancy without cervical lesions (age from 23 to 35 years) were observed. The control group consisted of 30 healthy non-pregnant women of reproductive age. In addition to general clinical 
examination colposcopic, cytological and microbiological studies were conducted, the level of local immunity (immunoglobulin (Ig) class A, M, G and SIgA) were measured in I, II and III trimesters of pregnancy.

Results and Discussion. The study proved that during pregnancy there are physiological changes in cervical mucosa. During colposcopy increased vascularization (14.5\%), epithelial edema (14.5\%), epithelial junction off set towards ectocervix (15.8\%), deciduosis (7.9\%), dumb iodine-negative zones (in $15.8 \%$ from the second trimester) were found. The frequency of these changes was increased with the course of pregnancy. Cytological study revealed the presence of cytolysis cells, prevalence of intermediate cell layers, signs of inflammation (14.5\%) and hyperkeratosis (10.5\% from the second trimester). The frequency of these events increased up to the third trimester. The study of local immunity parameters revealed marked increase of $\operatorname{lgA}(48.2 \pm 0.92 \mathrm{~g} / \mathrm{L})$ and slgA $(16.7 \pm 0.73 \mathrm{~g} / \mathrm{L})$ in vaginal-cervical flushing in the third trimester compared to the first and second trimesters $(p<0.05)$, indicating an increase in the protective properties of cervical mucosa before delivery. When the cervical mucosa was studied during pregnancy, mild cervical dysplasia was detected in the third trimester in $1(1.3 \%)$ patient with colposcopy and in $2(2.6 \%)$ with cytology.

Conclusions. A comprehensive assessment of the cervical mucosa in women with unchanged cervix showed that during pregnancy there are changes related to gestational remodelling influenced by hormonal, metabolic and immunological processes which are inherent to physiological pregnancy. Performance and correct interpretation of colposcopic, cytological, immunological screening results in pregnancy to exclude suspected precancerous and malignant cervical processes allows to detect the pathological process timely and to provide adequate treatment.

Key words: cervix; pregnancy; colposcopy; cytology.

ВСтУп. Патологія шийки матки становить 25-45\% від усіх гінекологічних захворювань [1]. Впровадження скринінгових програм щодо обстеження шийки матки у невагітних жінок у багатьох розвинутих країнах сприяло своєчасному виявленню доброякісних і передпухлинних станів шийки матки та їх адекватному лікуванню, що $€$ основним напрямком у профрілактиці раку шийки матки. На думку багатьох дослідників, саме результати скринінгових досліджень дозволяють фоомувати групи ризику для спостереження та проведення лікувальнопрофрілактичних заходів [1-3]. Особливо важливим $є$ визначення груп ризику серед жінок репродуктивного віку на прегравідарному етапі для проведення ранньої діагностики патологічних змін шийки матки і попередження ускладнень, які можуть виникнути під час вагітності.

На сьогодні відповідно до регламентуючих документів та наказів МО3 України всі вагітні при постановці на облік з приводу вагітності проходять повне обстеження шийки матки, яке включає кольпоскопію, цитологічне обстеження, інфеекційний скринінг (TORCH-комплекс). За результатами обстеження формуються групи ризику, за якими здійснюється контроль, проводиться профрілактика і своєчасно вирішується питання щодо тактики ведення вагітності та методу розродження [2].

В організмі вагітної жінки відбуваються зміни в усіх органах і системах, у тому числі і в шийці матки - важливій анатомічній та функціональній структурі, яка існує під час вагітності для утримання плода в порожнині матки до його народження $[4,5]$. Функціональний стан шийки матки забезпечується нормальною клітинною структурою епітелію, адекватними обмінними та проліферативними процесами під час вагітності, відсутністю активації патогенної мікрофрлори піхви й цервікального каналу $[2,6]$.

Функціональні зміни під час вагітності відбуваються в різних шарах шийки матки. В стромі спостерігається деструкція колагенових волокон з одночасним накопиченням глікопротеїнової субстанції. Утворюються нові кровоносні судини, збільшується матковий кровотік для підтримки росту плода. Строма інфрільтрується лейкоцитами, лімфоцитами та нейтрофрілами $[1,2]$.

Наслідком цих змін при вагітності є збільшення в розмірах, розм'якшення, гіперваскуляризація, зміна кольору шийки матки [1].
У багатошаровому плоскому епітелії піхвової частини шийки матки під час вагітності з'являється велика кількість клітин, які діляться 3 порушенням диференціації. Слизова оболонка цервікального каналу гіпертрофується за рахунок збільшення в розмірах клітин циліндричного епітелію і посилення в них процесів слизовиділення, що перешкоджає проникненню патогенної мікрофрлори. За рахунок гіпертрофії резервних клітин утворюються поліпоподібні вирости. На окремих ділянках має місце метаплазія циліндричного епітелію в багатошаровий плоский $[1,3,7,8]$

Гормональні зміни, до яких чутливий епітелій цервікального каналу, призводять під час вагітності до гіпертрофії шийки матки і змін ії структури. Внаслідок цього місце стику багатошарового плоского і циліндричного епітелію зміщується у більшості вагітних з цервікального каналу на піхвову частину шийки матки, утворюється так звана зона «ектопії вагітності», яка представлена гіпертросованим циліндричним епітелієм 3 набряком і васкуляризацією сосочків $[1,3,7,8]$.

Варіантом норми у вагітних жінок є децидуоз: екзофрітне розростання децидуальної тканини на шийці матки і в цервікальному каналі. Виділяють дві фрорми децидуозу: пухлиноподібну і поліпоподібну. Пухлиноподібний децидуоз має вигляд підвищення світло-рожевого або жовтуватого кольору з великою кількістю судин. Поліпоподібна форма децидуозу зустрічається частіше і має вигляд поліпа великих розмірів з дрібними судинами $[1,3,7]$.

3 огляду на фрізіологічну проліфрерацію епітелію, активну секрецію, набряк, посилену васкуляризацію, а іноді і децидуальну інфрільтрацію, оцінка змін шийки матки під час вагітності може бути утрудненою, що потребує знань характеристик стану шийки матки у вагітних, динамічного спостереження та додаткових методів обстеження.

Захворювання шийки матки, що виникають до/або під час вагітності, можуть впливати на перебіг вагітності і пологів. Частота патологічних змін шийки матки у вагітних складає 80 \% [3]. За даними літератури, в структурі захворювань шийки матки екзо- і ендоцервіцити становлять 76-90 \%, дисплазії - 33 \%, ектопії - 22-25 \%, поліпоподібні утворення - $10 \%[3,4,9]$.

Вагітність як фрізіологічний стан із властивими їй специфрічними особливостями метаболізму та імунного 
статусу може мати несприятливий (стимулюючий) вплив на клінічний перебіг патологічних станів шийки матки, що може обумовлювати виникнення раку. Поєднання вагітності і раку шийки матки у всьому світі складає 0,45-3,1 \% $[3,5,9]$ і є небезпекою не тільки для вагітної, а й для плода [3]. Клінічними спостереженнями доведено, що своєчасне виявлення та лікування патології шийки матки має суттєве значення в збереженні репродуктивного здоров'я жінки і профрілактиці раку шийки матки [1, 3, 5].

МЕТА ДОСЛІДЖЕННЯ - провести аналіз результатів комплексної оцінки стану шийки матки у здорових жінок протягом вагітності.

МАТЕРІАЛИ ТА МЕТОДИ. Під спостереженням перебувало 76 здорових жінок, які були взяті на облік з приводу вагітності без патологічних змін шийки матки віком від 23 до 35 років. Критеріями включення в дослідження були: репродуктивний вік пацієнтки, вагітність малого терміну, відсутність гінекологічних та соматичних захворювань. Критерії виключення - наявність посилань на патологію шийки матки до вагітності. Контрольну групу складали 30 здорових невагітних жінок репродуктивного віку.

Обстеження кожної жінки, крім загальноклінічних методів досліджень відповідно до наказу МОЗ України № 417, включало кольпоскопічне, цитологічне та мікробіологічне дослідження.

При кольпоскопічному дослідженні оцінювали стан епітелію і стикування різних його типів, рельєср поверхні шийки матки, стан підлеглої сполучної тканини. Розширена кольпоскопія включала огляд та оцінку стану піхвової частини шийки матки, піхви та вульви при збільшенні в 7-30 разів з використанням низки епітеліальних тестів для визначення реакції тканини у відповідь на обробку розчином Люголя і 3 \% оцтової кислоти.

Проведення розширеної кольпоскопії дозволяє не тільки визначити стан епітелію та судин, стан стикування епітелію шийки матки і цервікального каналу, а й виділити наявність патологічних вогнищ та їх межі, що дозволяє правильно, при необхідності, визначати місце біопсії, вибирати найбільш безпечні методи лікування для збереження максимального об'єму шийки матки, особливо у жінок, що не народжували.

Проста та розширена кольпоскопія з використанням тестів 3 3-5 \% розчином оцтової кислоти і 3 \% водним розчином Люголя (проба Шиллера) проводилась на апараті МК-200 (Україна).

Цитологічне дослідження є скринінговим методом у програмах профрілактики раку шийки матки. Цитологічне дослідження мазків із цервікального каналу і шийки матки оцінювали за Папаніколау (Pap-smear-test).

Інфекційний скринінг включав результати оцінки мазків на ступінь чистоти при бактеріоскопічному дослідженні, метод полімеразної ланцюгової ракції (ПЛР-діагностику), культуральний метод для ідентифрікації мікрофлори та визначення чутливості до антибіотиків [10]. Для виявлення уреаплазм та мікоплазм застосовували тест-системи Mycoplasma DUO. Хламідії та вірус папіломи людини (ВПЛ) виявляли методом ПлР. Крім того, в пробах крові визначали наявність антитіл до хламідій, вірусів групи герпесу I-II типів і цитомегаловірусу.

На сьогодні доведено, що місцевий імунітет відіграє важливу роль у захисті нижнього відділу статевих шляхів жінки, особливо під час вагітності. Для оцінки показників місцевого імунітету використовували змиви з піхви і шийки матки. Рівень імуноглобулінів (Ig) класів A, M, G та slgA визначали у твердофазовому ІФА з використанням тестсистем виробництва «Вектор-Вест» (Росія).

Кольпоскопічне, цитологічне дослідження та визначення показників місцевого імунітету проводили в I, II та III триместрах вагітності.

Статистичну обробку отриманих даних здійснювали за допомогою стандартних програм статистичного аналізу (GraphPad Insstant, Stastica for Windows v.7.0, Microsoft Excel 2003 та ін.), оцінюючи вірогідність на рівні значимості не менше $95 \%(P \leq 0,05)$ та за допомогою критерію t Стьюдента.

РЕЗУЛЬТАТИ ДОСЛІДЖЕННЯ ТА ЇХ ОБГОВОРЕННЯ. Середній вік жінок основної групи становив $(27,7 \pm 2,1)$ року, контрольної - $(26,8 \pm 1,8)$ року. В процесі обстеження встановлено, що в анамнезі більшість жінок основної групи - 71 (93,4 \%) мали своєчасне настання менархе, ранній початок статевого життя мала 21 (27,6 \%) пацієнтка. В контрольній групі, відповідно, - 28 (93,3 \%) і 9 (30,0 \%). Першонароджуючих серед жінок основної групи було 55 (72,4 \%), повторнонароджуючих - 21 (27,6 \%). 3 числа обстежених жінок вагітність раніше мали: в основній групі - 31 (40,8 \%), в контрольній групі - 13 (43,3\%). Вагітності закінчились пологами у 21 (27,6 \%) жінки основної групи і у 8 (26,7 \%) контрольної групи, штучними абортами -у $14(18,4 \%)$ і 5 (16,7 \%) відповідно.

За результатами комплексного обстеження визначеного контингенту пацієнток було встановлено, що 3 I триместру у вагітних відмічаються зміни, які відображають перебудову даного відділу статевих шляхів до гестаційного періоду.

При огляді в дзеркалах у пацієнток основної групи, на відміну від жінок контрольної групи, відмічались зміни піхви і шийки матки, характерні для вагітності. Слизова піхви на ранніх термінах мала темно-синій колір і з пролонгацією вагітності набувала синьо-багряного відтінку. Спостерігались набряк слизової оболонки піхви, складчастість стінок. Ціаноз слизової шийки матки відмічено у всіх жінок, гіпертрофію шийки матки - у 11 (14,5 \%), незначне зіяння зовнішнього вічка - у 52 (68,4 \%), фрізіологічну ектопію - у 12 (15,8 \%), децидуоз - у 6 (7,9\%).

При проведенні простої кольпоскопії у пацієнток основної групи відмічено гіпертрофрію і ціаноз шийки матки, чіткий і виразний судинний малюнок, незначне зіяння зовнішнього вічка. Кількість вивідних проток і розміри фрункціонуючих залоз збільшується. При фрізіологічній ектопії виявлено посилену васкуляризацію сосочків, які з пролонгацією вагітності подовжувались, мали яскраворожевий колір і нагадували поліпоподібні розростання. Після тесту з 3 \% розчином оцтової кислоти набряк і розширення судин майже повністю зникали.

Протягом вагітності у 63 (82,9 \%) жінок спостерігались зміни цервікального слизу, який ставав в'язким і мутним білого або жовтуватого кольору. В більшості випадків $(92,1 \%)$ виникали труднощі з його видаленням при пробі з $3 \%$ розчином оцтової кислоти.

При пробі Шиллера (з 3 \% розчином Люголя) у більшості вагітних відмічено інтенсивне забарвлення слизової оболонки шийки матки в темно-коричневий колір. 3 ІІ триместру у 12 (15,8 \%) вагітних спостерігались йоднегативні ділянки по всій поверхні шийки матки. Нечіткі межі 
між зоною трансформації і йодпозитивною слизовою оболонкою шийки матки можуть свідчити про доброякісні фрізіологічні зміни.

3 ранніх термінів відмічено наявність децидуозу шийки матки, частота якого зростала з пролонгацією вагітності. При простій кольпоскопії ділянки децидуозу мали вигляд вузлових утворень з посиленою васкуляризацією і аморфною поверхнею у вигляді шароподібних або поліпоподібних розростань жовтувато-рожевого кольору. У 2 (2,6 \%) пацієнток децидуоз мав вигляд незначного підвищення навколо вивідних проток залоз.

Фізіологічні зміни шийки матки протягом вагітності при кольпоскопічному дослідженні представлені в таблиці 1.

3 даних таблиці видно, що частота виявлених змін зростала з пролонгацією вагітності. Німі йоднегативні зони відмічено лише в II і III триместрах.

У 1 (1,3\%) жінки основної групи при розширеній кольпоскопії в III триместрі виявлено ділянки ніжної мозаїки.

У жінок контрольної групи при проведенні простої кольпоскопії шийка матки була вкрита багатошаровим плоским епітелієм, який мав гладку, блискучу поверхню світло-рожевого кольору з ніжним судинним малюнком. При обробці розчином оцтової кислоти багатошаровий плоский епітелій ставав блідим, при пробі Шиллера рівномірно забарвлювався в темно-коричневий колір.

Цитологічними особливостями незміненої шийки матки під час вагітності була наявність реактивних змін у мазках. Відмічено наявність цитолізу клітин, переважання клітин проміжних шарів, гіперкератозу, ознак запалення (табл. 2).

3 представлених даних видно, що запальний тип цитологічного мазка виявлявся у незначної частини жінок, його частота зростала до III триместру вагітності. Цитологічні ознаки папіломавірусної інфееції (койолоцити) діагностовано у 4 (5,3 \%) вагітних лише в III триместрі. Гіпер- і паракератоз виявлено в II і III триместрах. У 1 (1,3 \%) вагітної в II триместрі та у 2 (2,6 \%) - в III триместрі виявлено дисплазію легкого ступеня при цитологічному дослідженні. Всі пацієнтки контрольної групи мали цитологічні мазки I типу (без особливостей).

У вагітних в I триместрі та жінок контрольної групи при бактеріоскопічному дослідженні відмічено II ступінь чистоти піхви. III ступінь чистоти піхви визначався у 5
(6,6 \%) вагітних в II триместрі і у 6 (7,9\%) - в III триместрі, що потребувало проведення санації піхви. Результати мікробіологічних досліджень показали, що в жінок основної групи виявлялись представники умовно-патогенної мікрофрлори (Mycoplasma hominis, Ureaplasma urealiticum, Gardnerella vaginalis) у низькому мікробному числі $\left(<10^{4}\right.$ КOE/г) - у 9 (11,8 \%), у $7(9,2 \%)$ і у $14(18,4 \%)$ пацієнток відповідно. У жінок контрольної групи вказані збудники визначались у 3 (10,0 \%), у 1 (3,3 \%) і у 4 (13,3 \%) відповідно. Gardnerella vaginalis у високому мікробному числі (>104 KOE/г) діагностована у 2 (2,6 \%) вагітних в II триместрі і у 3 (3,9 \%) - в III триместрі. Mycoplasma hominis у високому мікробному числі (>104 KOE/г) виявлялась у 2 (2,6 \%) вагітних в II триместрі і у 1 (1,3\%) - в III триместрі. Віруси виявлено у 12 (15,8 \%) жінок основної групи: вірус папіломи людини низького онкогенного ризику (типи $6,11)$ - у 4 (5,3\%), IgM до вірусу простого герпесу 1-2 типів - у $5(6,6 \%)$ та цитомегаловірусу - у 3 (3,9\%). У 1 (1,3\%) вагітної жінки в III триместрі виявлено ВПЛ 33 типу. Віруси у жінок контрольної групи не визначались. Аналіз бактеріологічного дослідження показав, що у 54 (71,1 \%) вагітних в I триместрі і у 25 (83,3 \%) - контрольної групи переважали лактобактерії та біфрідумбактеpiї. Представники неспецисрічної мікрофрлори (E. coli, St. aureus, St. epidermalis, Enterococcus faecalis) у низькому мікробному числі (<103 KOE/г) виявлялись у 11 (14,5\%) жінок основної групи і у 5 (16,7 \%) - контрольної групи. Гриби роду Candida діагностовано у 8 (10,5 \%) вагітних в II триместрі і у 11 (14,5 \%) - в III триместрі. Проведення мікробіологічного дослідження в різні терміни вагітності дозволило виявити патогенні збудники і своєчасно провести санацію.

Таким чином, комплексна оцінка стану шийки матки протягом вагітності може допомогти своєчасно виявити патологічні зміни шийки матки і сорормувати групи ризику по розвитку передракових захворювань і раку шийки матки.

Особлива роль у захисті органів, що стоять на межі із зовнішнім середовищем, належить місцевому імунітету. Результати дослідження стану гуморальної ланки місцевого імунітету слизової шийки матки у вагітних у різні терміни і у здорових невагітних жінок представлені в таблиці 3.

Таблиця 1. Результати кольпоскопічної оцінки у жінок основної групи (абс. число (\%))

\begin{tabular}{|l|c|c|c||}
\hline \multirow{2}{*}{\multicolumn{1}{|c|}{ Ознаки }} & \multicolumn{2}{c||}{ Триместри вагітності } \\
\cline { 2 - 4 } & І триместр & II триместр & III триместр \\
\hline Посилення васкуляризації & $11(14,5)$ & $15(19,7)$ & $18(23,7)$ \\
\hline Гіпертросрія & $11(14,5)$ & $15(19,7)$ & $18(23,7)$ \\
\hline Фізіологічна ектопія & $12(15,8)$ & $14(18,4)$ & $17(22,4)$ \\
\hline Децидуоз & $6(7,9)$ & $9(11,8)$ & $11(14,5)$ \\
\hline Німі йоднегативні зони & - & $12(15,8)$ & $12(15,8)$ \\
\hline
\end{tabular}

Таблиця 2. Результати цитологічного дослідження вагітних жінок (абс. число (\%))

\begin{tabular}{|c|c|c|c|}
\hline \multirow{2}{*}{ Ознаки } & \multicolumn{3}{|c|}{ Триместри вагітності } \\
\hline & I триместр & II триместр & III триместр \\
\hline Гіперкератоз & - & $8(10,5)$ & $9(11,8)$ \\
\hline Запальний тип & $11(14,5)$ & $13(17,1)$ & $17(22,4)$ \\
\hline Койолоцити & - & - & $4(5,3)$ \\
\hline
\end{tabular}


Акушерство та гінекологія -

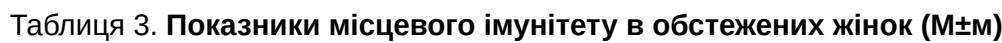

\begin{tabular}{|c|c|c|c|c|}
\hline \multirow{2}{*}{ Показник } & \multicolumn{3}{|c|}{ Основна група, n=76 } & \multirow{2}{*}{ Контрольна група, n=30 } \\
\hline & I триместр & II триместр & III триместр & \\
\hline $\operatorname{lgG}$, г/л & $43,8 \pm 1,56$ & $42,6 \pm 1,34$ & $45,1 \pm 1,78$ & $44,6 \pm 1,43$ \\
\hline $\lg \mathrm{M}$, г/л & $1,9 \pm 0,96$ & $2,6 \pm 0,72$ & $2,1 \pm 0,67$ & $2,2 \pm 0,76$ \\
\hline $\lg \mathrm{A}$, г/л & $26,7 \pm 0,89^{\star}$, ,**, & $35,6 \pm 0,77^{*}$,** & 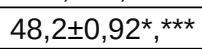 & $20,1 \pm 0,92^{\star}$ \\
\hline $\operatorname{slg} \mathrm{A}$, г/л & 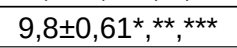 & $12,8 \pm 0,87^{*}$,** & $16,7 \pm 0,73^{*}$, ,** & $6,4 \pm 0,53^{\star}$ \\
\hline
\end{tabular}

Примітка. Вказана достовірна різниця $\left(\right.$ р<0,05) відносно: *- показників в основній і контрольній групах; ${ }^{*}-$ показників в I i II триместрах; ${ }^{* *}$ - показників в I і III триместрах.

Аналіз показників місцевого імунітету показав, що рівень lgG i lgM суттєво не відрізнявся у пацієнток основної контрольної груп та не змінювався протягом вагітності. Що стосується IgA і slgA, то їх рівень був достовірно $(p<0,05)$ вищим у вагітних жінок порівняно з невагітними здоровими жінками. Концентрація IgA і slgА достовірно $(p<0,05)$ підвищувалась в II i, особливо, в III триместрах. Зростання рівня slgA у вагітних в 34-39 тижнів може свідчити про підвищення захисних властивостей цервікального слизу, що сприяє перешкоджанню проникнення інфекційних чинників в епітеліальні клітини шийки матки перед пологами запобіганню розвитку внутрішньоутробного інфікування.

ВИснОВКИ. Комплексна оцінка стану слизової шийки матки у жінок з незміненою шийкою матки показала, що під час вагітності відбуваються фрізіологічні зміни, які встановлені за результатами досліджень:

1. При кольпоскопічному дослідженні: посилення васкуляризації, набряк епітелію, зміщення стику епітелію в бік ектоцервіксу, німі йоднегативні зони, децидуоз. Частота і характер виявлення даних змін зростає з пролонгацією вагітності.

\section{СПИСОК ЛІТЕРАТУРИ}

1. Русакевич П. С. Заболевания шейки матки у беременных: диагностика, лечение, мониторинг, профилактика/ П. С. Русакевич, Т. М. Литвинова. - М. : ООО «Медицинское информационное агентство», 2006. - 144 с.

2. Жабченко І. А. Особливості ведення вагітних з патологією шийки матки / І. А. Жабченко // Здоров'я України. - 2011. - Червень (Тематичний номер). - С. 16-17.

3. Зароченцева Н. В. Заболевания шейки матки при беременности (современные аспекты диагностики и тактики ведения) : автореф. дисс. на получение научной степени д-ра мед. наук: спец. 14.01.01 «Акушерство и гинекология»/ Н. В. Зароченцева. - М., 2009. - 45 с.

4. Сидорова И. С. Методы исследования шейки матки у беременных женщин / И. С. Сидорова, Д. А. Атабиева // Акушерство, гинекология, репродуктология. - 2013. - Т. 7, № 2. - С. 15-19.

5. Хафризова Н. А. Патология шейки матки у женщин с потерями беременности : авторефр. дисс. на получение научной степени канд. мед. наук: спец.14.01.01 «Акушерство и гинекология» / Н. А. Хафизова. - Душанбе, 2012. - 22 с.
2. При цитологічному дослідженні: наявність цитолізу клітин; переважання клітин проміжних шарів; наявність гіперкератозу і ознак запалення, частота яких зростає до III триместру вагітності.

3. Підвищення рівня IgA та slgA в піхвово-цервікальних змивах в III триместрі вагітності, що свідчить про підвищення захисних властивостей цервікального слизу перед пологами.

Отримані результати дозволяють своєчасно і правильно проводити інтерпретацію клінічних даних при патології шийки матки у вагітних та попередити ускладнення вагітності та пологів.

Комплексне дослідження стану шийки матки протягом вагітності може допомогти своєчасно виявити патологічні зміни шийки матки і сорормувати групи ризику по розвитку передракових захворювань і раку шийки матки.

ПЕРСПЕКТИВИ ПОДАЛЬШИХ ДОСЛІДЖЕНЬ. ДОслідити кольпоскопічні та цитологічні особливості різних патологічних станів шийки матки протягом вагітності.

6. House M. The cervix as biomechanical structure / M. House, S. Socrate // Ultrasound Obstet. Gynecol. - 2006. № 28. - P. 745-749.

7. Роговская С. И. Практическая кольпоскопия / С. И. Роговская. - М. : ГЭОТАР-Медиа, 2011. - 232 с.

8. Торшина 3. В. Особенности местного иммунитета у беременных с папилломавирусной инфекцией и возможности иммунокорригирующей терапии : автореф. дисс. на получение научной степени канд. мед. наук: спец. 14.01.01, 14.03.09 «Акушерство и гинекология», «Клиническая иммунология, аллергология» / 3. В. Торшина. - М., 2014. - 23 с.

9. Cervical Intraepithelial Neoplasia (CIN) in pregnancy: the state of the art / M. Origoni, S. Salvatore, A. Perino [et al.] // European Review for Medical and Pharmacological Sciences. - 2014. - № 18. - P. 851-860.

10. Медицинская лабораторная диагностика (программы и алгоритмы). Т. 3 / под ред. А. И. Карпищенко. - СПб. : Интермедика, 2001. - 544 с. 


\section{REFERENCES}

1. Rusakevich, P.S., \& Litvinova, T.M. (2006). Zabolevania sheiki matki u beremennyh: diagnostika, lechenie, monitoring, profilaktika [Cervical diseases in pregnancy: diagnosis, treatment, monitoring, prevention]. Moscow: Meditsinskoie informatsionnoe agentstvo [in Russian].

2. Zhabchenko, I.A. (2011). Osoblyvosti vedennia vahitnykh z patolohiieu shyiky matky [Management of pregnancy with cervical pathology]. Zdorovia Ukrainy - Health of Ukraine, 1617 [In Russian].

3. Zarochentseva, N.V. (2009). Zabolevania sheiki matki pri beremennosti (sovremennye aspekty diagnostiki i taktiki vedeniya) [Cervical diseases in pregnancy (modern aspects of diagnostics and management]. Extended abstract of Doctor's thesis. Moscow: MONIIAG [in Russian].

4. Sidorova, I.S. \& Atabieva, D.A. (2013). Metody issledovaniya sheiki matki u beremennykh zhenshchin [Methods of cervical investigation in pregnant women]. Akusherstvo, ginekologiya, reproduktologiya - Obstetrics, Gynecology, Reproductology, 2 (7), 15-19 [in Russian].

5. Hafizova, N.A. (2012). Patologiya sheiki matki u zhenshchin $s$ poteriami beremennosti [Cervical pathology in women with recurrent losses]. Extended abstract of candidate's thesis. Dushanbe: TajSI [in Russian].

6. House, M. (2006). The cervix as biomechanical structure. Ultrasound Obstet. Gynecol., 28, 745-749.

7. Rogovskaya, S.I. (2011). Prakticheskaya kolposkopiya [Practical colposcopy]. Moscow: GEOTAR-Media [In Russian].

8. Torshina, Z.V. (2014). Osobennosti mestnogo immuniteta $\mathrm{u}$ beremennyh s papillomavirusnoi infektsiei i vozmozhnosti immunokorrigiruyushchei terapii [Special aspects of local immunity in pregnant women with papilloma infection and possibilities of immune correction therapy]. Extended abstract of candidate's thesis. Moscow: FSBU NIIEM [In Russian].

9. Origoni, M., Salvatore, S., Perino, A., Cucinella, G., \& Candiani, M. (2014). Cervical Intraepithelial Neoplasia (CIN) in pregnancy: the state of the art. European Review for Medical and Pharmacological Sciences, 18, 851-860.

10. Karpishchenko, A.I. (2001). Meditsinskaya laboratornaya diagnostika (programmy I algoritmy) [Medical Laboratory diagnostics (programs and algorithms]. S. Peterburg: Intermedika [in Russian]. 